\title{
CRAYFISH MANAGEMENT FOR SWISS WATERS
}

\author{
D. HEFTI (1) AND P. STUCKI (2)
}

(1) Federal office for the Environment. Species Management. $3003 \mathrm{CH}-B e r n e$, Switzerland.

E-Mail: daniel.hefti@buwal.admin.ch

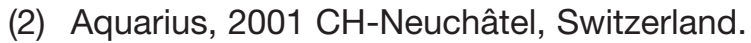

E-Mail: aquarius@vtx.ch

Reçu le 16 juin 2005

Accepté le 5 décembre 2005

Received June 16, 2005

Accepted December 5, 2005

\begin{abstract}
Seven species of crayfish are present in Swiss waters: three native ones (Astacus astacus, Austropotamobius pallipes, Austropotamobius torrentium) and four exotic ones (Astacus leptodactylus, Orconectes limosus, Pacifastacus leniusculus, Procambarus clarkii). The occurrence of each species is known and distribution maps have been drawn at national level. Many of the non-native populations have been identified as carriers of the crayfish plague, acting as a vector for Aphanomyces astaci. Crayfish are regulated by the Swiss Fisheries Legislation. The catching of the native species is allowed but the effective fishing pressure is low. The non-native species are considered as undesirable. For that reason importation, introduction and transportation of live specimens are forbidden with the exception of Cherax sp. which may be kept in cool boxes without any contact with water until consumption. A national management plan has been developed by the Federal Office for the Environment. It aims at increasing protective measures for the native species and enhancing population control for the non-native ones. The elimination measures are targeted on the most problematic species Pacifastacus leniusculus and Procambarus clarkii.
\end{abstract}

Key-words: crayfish, management, conservation, legislation, distribution, crayfish plague.

\section{GESTION DES ÉCREVISSES DANS LES EAUX SUISSES}

\section{RÉSUMÉ}

Sept espèces d'écrevisses sont présentes dans les eaux suisses: trois sont indigènes (Astacus astacus, Austropotamobius pallipes, Austropotamobius torrentium) et quatre sont exotiques (Astacus leptodactylus, Orconectes limosus, Pacifastacus leniusculus, Procambarus clarkii). L'occurrence de chaque espèce ainsi que des cartes de distribution à l'échelle nationale ont été établies. De nombreuses populations exotiques portent le vecteur de la peste de l'écrevisse Aphanomyces astaci. Les écrevisses sont réglementées par la législation fédérale sur la pêche. La capture des espèces indigènes est autorisée mais la pression de pêche demeure faible. Les espèces exotiques sont indésirables; c'est pourquoi, leur importation, introduction et transport vivants sont prohibés à l'exception des individus du genre Cherax lorsqu'ils demeurent confinés dans 
des récipients réfrigérés et fermés. L'Office Fédéral de l'Environnement a développé un plan de gestion qui vise à renforcer les mesures de protection des populations indigènes et à limiter le développement des populations exotiques. Les mesures d'élimination sont ciblées sur les espèces les plus problématiques, à savoir Pacifastacus leniusculus et Procambarus clarkii.

Mots-clés : écrevisses, gestion, conservation, législation, distribution, peste de l'écrevisse.

\section{INTRODUCTION}

For the past few years, the Federal Office for the Environment (FOEN) has been formulating a strategy for the long-term conservation of crayfish at national level with the support of the cantons. To achieve such a goal some basic requirements have to be fulfilled (Figure 1): the conservation program has to be documented on the basis of objective criteria (scientific component); the measures to be implemented have to be integrated into a coherent and operative policy (political component) and they have to be in adequacy with the expectations of the stakeholders (social component). The strategy proposed in this paper was performed in different steps. We first elucidated the distribution of each species and that of the crayfish plague (Aphanomyces astaci) at national level. Together with the ecological requirements of each species, this information forms the scientific basis of the management strategy. We further define the degree of threat for each native species as well as a catalogue of measures to be implemented. These measures were formalized in the Legislation by restricting the importation and introduction of non-native species and by controlling the expansion of the most problematic ones. Finally, an action plan was developed, reinforcing protective measures for native species and enhancing population control for the non-native ones.

Species composition

Distribution

Biology

Ecology

Degree of threat

Crayfish plague

Database

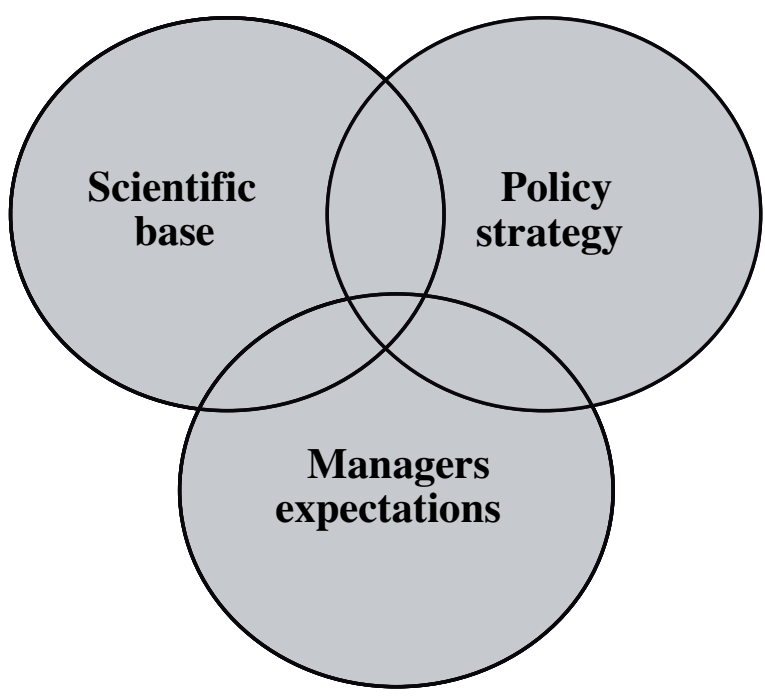

Fisheries legislation

Red list

Close season

Minimum size

Importation

Introduction

Fighting measures

Crayfish management plan

\section{Figure 1}

Three main aspects to consider when developing a management plan at national scale.

\section{Figure 1}

Les trois composantes principales à considérer dans le cadre d'un plan de gestion à échelle nationale. 


\section{CRAYFISH SPECIES IN SWISS WATERS}

The first information related to crayfish distribution in Swiss waters came from Carl $(1917,1920)$. At that time, Swiss waters were only colonized by the three native species: Astacus astacus, Austropotamobius pallipes and Austropotamobius torrentium. Despite the presence of large populations, CARL $(1917,1920)$ already mentioned a marked decline, mainly due to the crayfish plague (its propagation through Europe exterminated most stocks of native species between 1880 and 1900) and, locally, due to acute water pollutions. BOTT (1972) confirmed and completed CARL's distribution survey (1917, 1920); at that time the author did not report any alien crayfish species. The first catches of Orconectes limosus in 1976 and of Astacus leptodactylus in 1979 were reported in Lake Geneva by LAURENT (1983). The presence of both species in other Swiss water bodies was confirmed by BÜTTIKER (1980) as well as the suspected occurrence of Pacifastacus leniusculus (BÜTTIKER, 1987). Procambarus clarkii was first mentioned by STUCKI (1997). STUCKI and JEAN-RICHARD (1999) produced the first Swiss crayfish atlas. Besides the three native species, the authors established the distribution of $A$. leptodactylus, O. limosus, P. leniusculus and P. clarkii. Some specimens of Yabbies (Cherax sp.) were once observed in the wild but did not seem to survive because the establishment of a natural population has not so far been confirmed.

The database used for the atlas of STUCKI and JEAN-RICHARD (1999) was continuously updated during the following years and managed by the Swiss Center for Cartography of the Fauna (CSCF) in Neuchâtel. Today it contains more than 3.000 sites, 2.081 of them with crayfish occurrences (Table I) forming the basis for the following distribution maps and the current national status for each species (STUCKI and ZAUGG, 2005).

\section{Table I}

\section{Swiss national crayfish database.}

\section{Tableau I}

Base de données nationale sur les écrevisses.

\begin{tabular}{|l|c|c|c|}
\hline \multicolumn{1}{|c|}{ Water bodies } & Total & $\begin{array}{c}\text { Lakes and } \\
\text { ponds }\end{array}$ & $\begin{array}{c}\text { Rivers and } \\
\text { brooks }\end{array}$ \\
\hline No. of sites investigated & 3.208 & 708 & 2.500 \\
\hline No. of sites with crayfish occurrences & 2.081 & 555 & 1.526 \\
\hline No. of sites containing native crayfish & 1.578 & 367 & 1.211 \\
\hline $\begin{array}{l}\text { No. of sites containing non-native } \\
\text { crayfish }\end{array}$ & 499 & 211 & 288 \\
\hline $\begin{array}{l}\text { No. of sites containing native and } \\
\text { non-native crayfish }\end{array}$ & 62 & 51 & 11 \\
\hline
\end{tabular}

\section{DISTRIBUTION OF CRAYFISH SPECIES}

During the last ten years, a great number of native populations of crayfish have disappeared. The populations still surviving today are residual and isolated populations often located in the head of catchment areas or remote ponds. Among the different causes affecting the integrity of rivers and ponds, the following are considered to play a relevant role in the regression of the native species:

- Physical alteration of river systems and the disappearance of wetlands (damming, correction, rectification, elimination of water courses). 
- Insufficient water quality.

- Competition generated by non-native crayfish species.

- Crayfish plague (Aphanomyces astaci).

- Inadequacy of fisheries management (intensive stocking).

\section{Astacus astacus}

Originating from the Northeastern part of Europe the noble crayfish was introduced in Switzerland during the Middle Ages for human consumption. The species lives in lakes, ponds, brooks and rivers with a maximum recorded occurrence at $1.800 \mathrm{~m}$ in elevation. The actual distribution of the species (Figure 2) covers the whole of Switzerland with the exception of the Southern part of the Alps. The populations are partly exploited and are generally in regression. The species is considered as endangered.

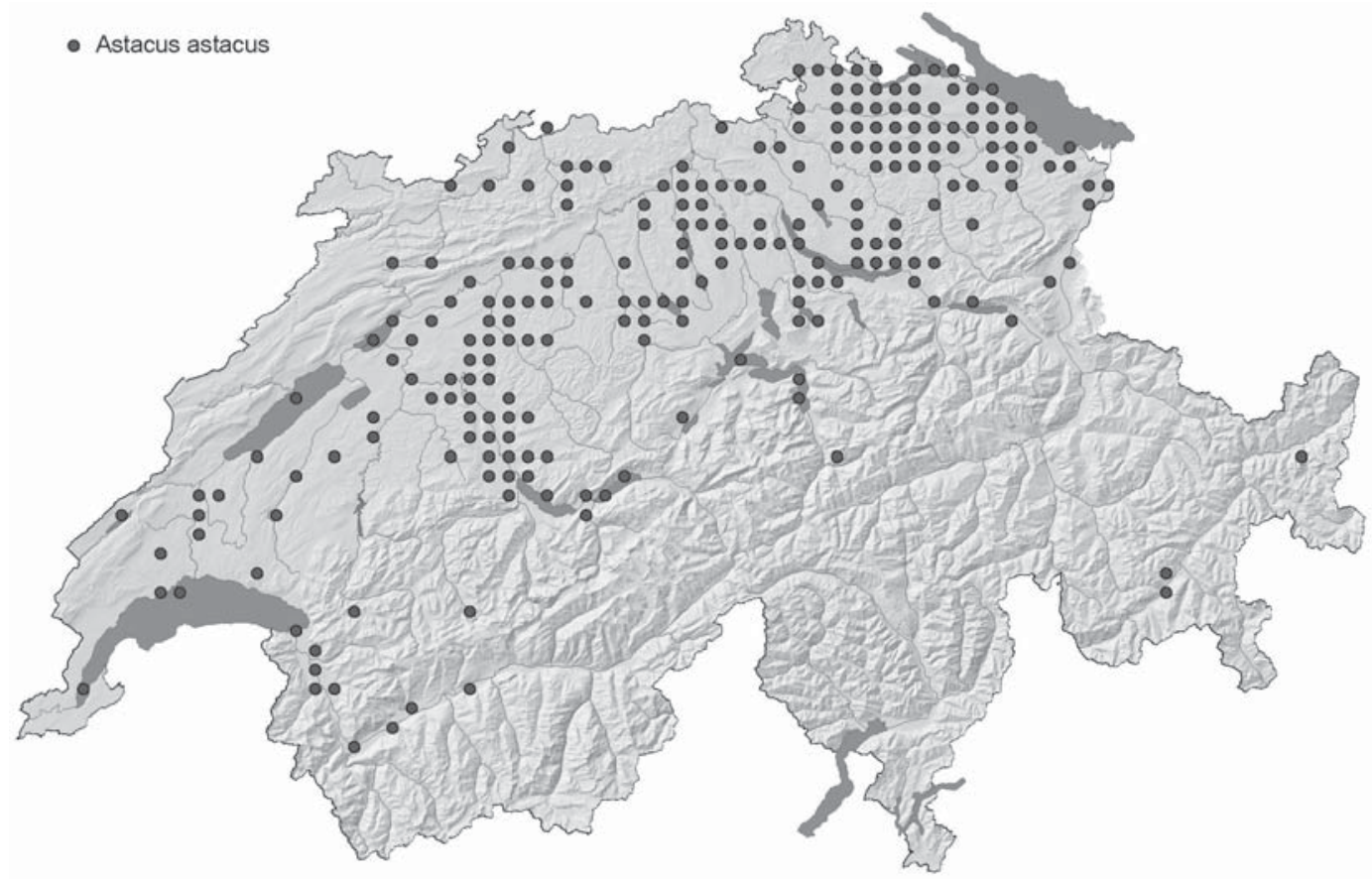

Figure 2

Current distribution of $A$. astacus. Each point represents a crayfish occurrence on a $5 \times 5 \mathrm{~km}$ grid.

\section{Figure 2}

Carte de distribution actuelle de $A$. Astacus. Chaque point représente une occurrence sur une grille de $5 \times 5 \mathrm{~km}$.

\section{Austropotamobius pallipes}

The white-clawed crayfish colonized Swiss waters after the last glaciations. The species lives in brooks, canals and ponds with a highest recorded occurrence at $1.450 \mathrm{~m}$ in elevation. Its current distribution (Figure 3 ) is restricted to the Northwestern part of Switzerland with presence in the Southeastern part of the Alps, where the species has been introduced (OBRECHT and NIGGLI, 1929). MADDALENA et al. (1998) established the distribution of the species in the Southern part of the Alps. The white-clawed crayfish is of low economic interest and is considered as strongly endangered. The A. pallipes 


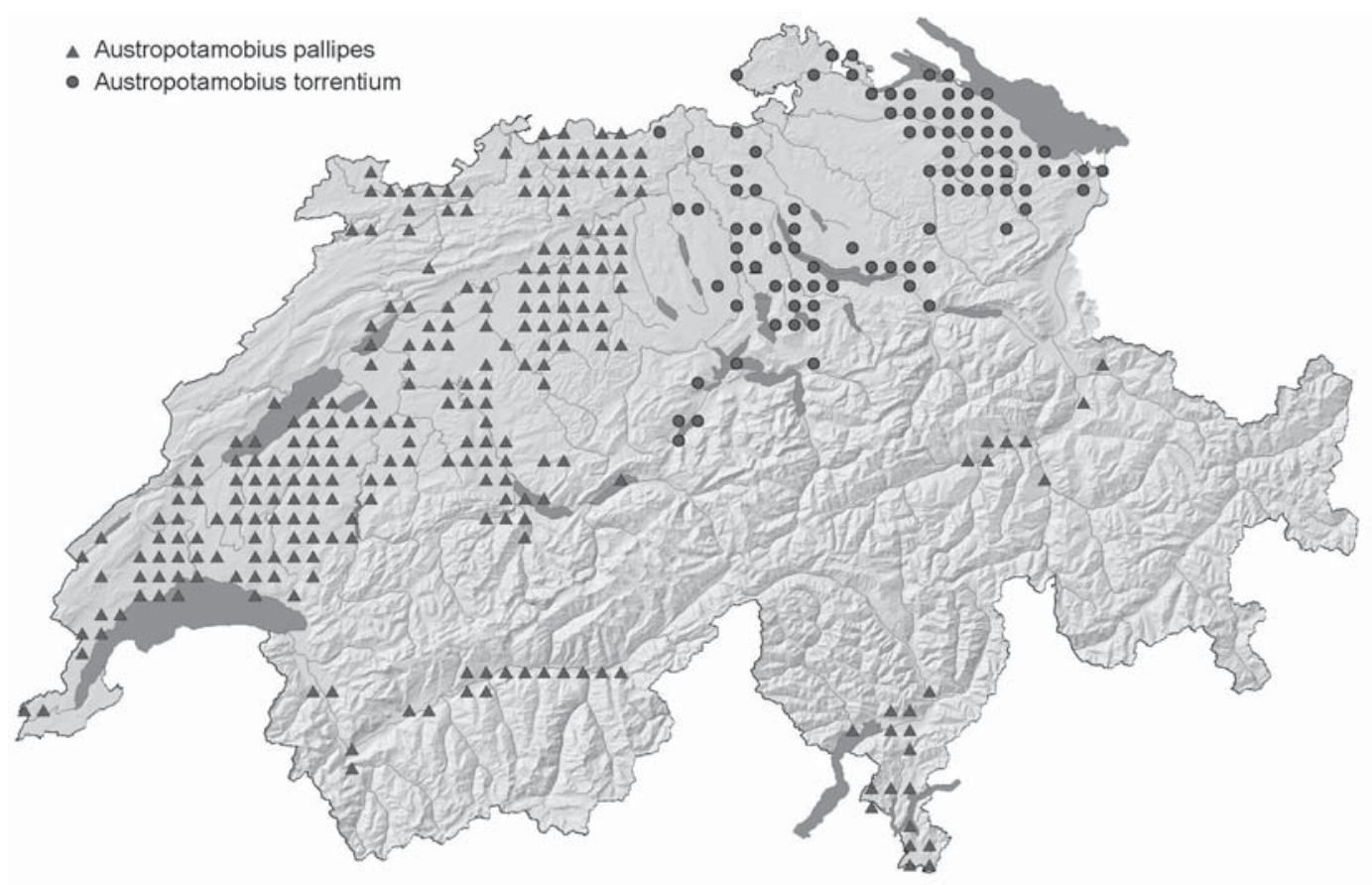

Figure 3

Current distribution of $A$. pallipes and of $A$. torrentium. Each point represents a crayfish occurrence on a $5 \times \mathbf{5} \mathbf{~ k m}$ grid.

\section{Figure 3}

Carte de distribution actuelle de $A$. pallipes et de $A$. torrentium. Chaque point représente une occurrence sur une grille de $5 \times 5 \mathrm{~km}$.

complex in Switzerland was studied genetically by LÖRTSCHER et al. (1997). Based on allozyme variations, the authors described three major lineages. Using nuclear (allozyme) and mitochondrial markers, LARGIADĖR et al. (2000) described five genetically distinct groups of the species-complex in the Alpine region. The geographical distribution of these evolutionary lineages coincided largely with several taxa (A.p. pallipes, A. berndhauseri, A.p. italicus) formerly described on the basis of morphological criteria.

\section{Austropotamobius torrentium}

The stone crayfish colonized Swiss waters after the last glaciations. The species shows a preference for clear and turbulent brooks with hard substrate (STUCKI and ROMER, 2001) as well as the littoral zones of small lakes (highest occurrence: $900 \mathrm{~m}$ in elevation). The occurrence of the species is restricted to the Northeastern part of Switzerland (Figure 3). The stone crayfish presents no economic interest and is considered as strongly endangered.

\section{Astacus leptodactylus}

The narrow-clawed crayfish was introduced into Swiss waters at the end of the 1970s from the East (mainly Turkey) for gastronomic purposes and to compensate for the disappearance of $A$. astacus. The species inhabits lakes, ponds and rivers from the plain where it can build large populations. It shows a scattered distribution in the Rhine and Rhone catchment areas and, marginally, in the Southern part of the Alps (Figure 4). Like native species, $A$. leptodactylus is vulnerable to the crayfish plague and some large populations have been decimated recently (STUCKI and STAUB, 1999). The species seems to be in regression in Switzerland. 


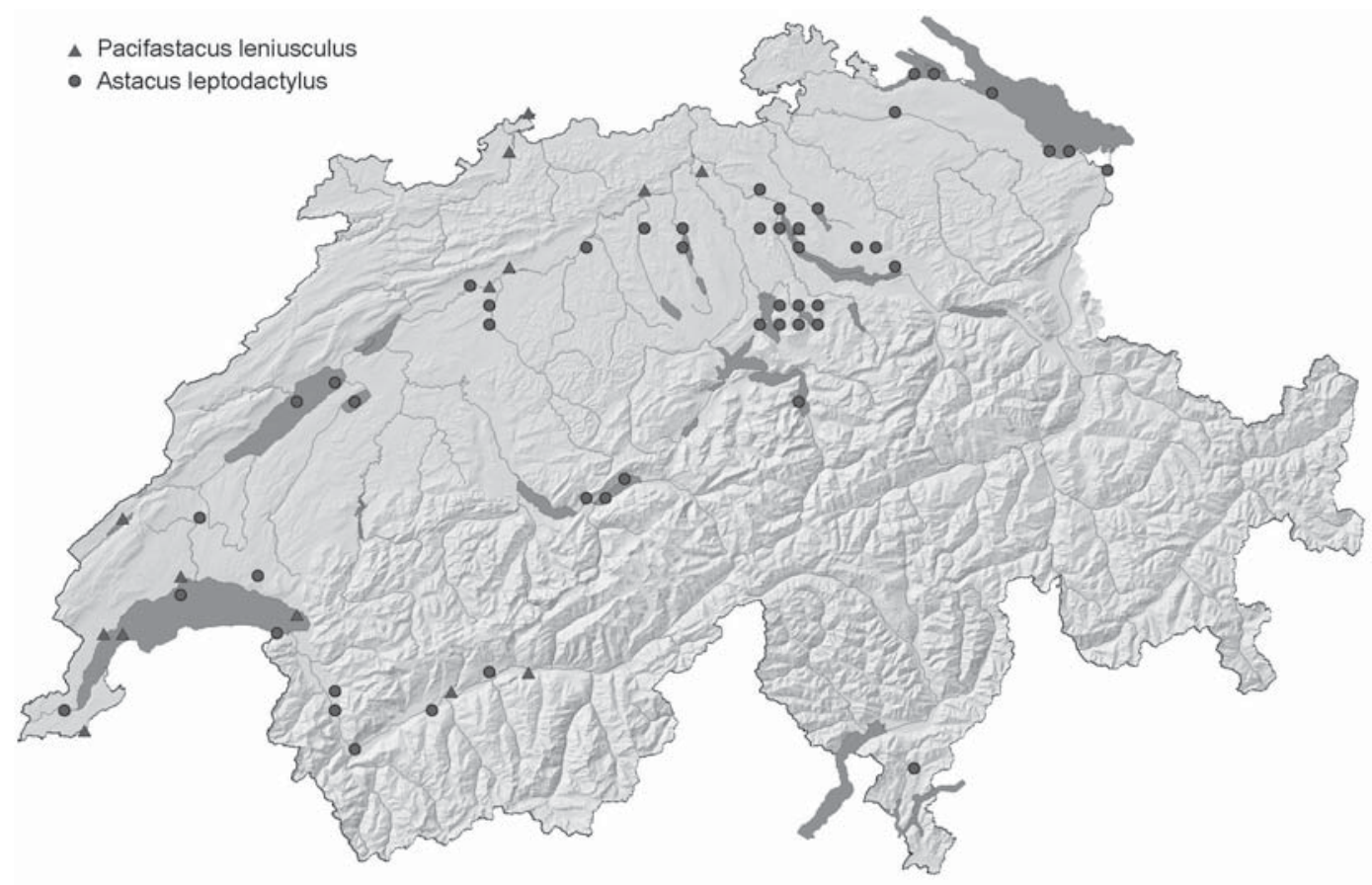

Figure 4

Current distribution of $A$. leptodactylus and of $P$. leniusculus. Each point represents a crayfish occurrence on a $5 \times 5 \mathrm{~km}$ grid.

\section{Figure 4}

Carte de distribution actuelle de $A$. leptodactylus et de $P$. leniusculus. Chaque point représente une occurrence sur une grille de $5 \times 5 \mathrm{~km}$.

\section{Orconectes limosus}

The spiny-cheek crayfish comes from North America and was introduced in the 1970s. Today, the species is widely distributed in large streams, canals and lakes and has been recorded at elevations of up to $800 \mathrm{~m}$ (Figure 5). Until now the species has never been recorded in turbulent brooks and does not seem to migrate upstream into small tributaries where the native crayfish still live (MICKASCH, 1999). The species is in expansion.

\section{Pacisfastacus leniusculus}

The North American signal crayfish was introduced to Swiss waters in the 1980s. The species inhabits ponds and rivers from the plain and higher regions (recorded at elevations of up to until $1.000 \mathrm{~m}$ ). The species exhibits a scattered distribution (Figure 4), colonizing a restricted number of water bodies and the same type of habitat as $O$. limosus. The species has the potential to migrate upstream into smaller rivers threatening the native species. Thus it is considered as an invasive species.

\section{Procambarus clarkii}

The red swamp crayfish was introduced to Swiss waters during the 1990s for unknown reasons. Until now, the species (Figure 5) has been restricted to four sites in the plain (one river and three ponds). Because of its behavioral characteristics and its potential physiological adaptations the species is considered as invasive. 


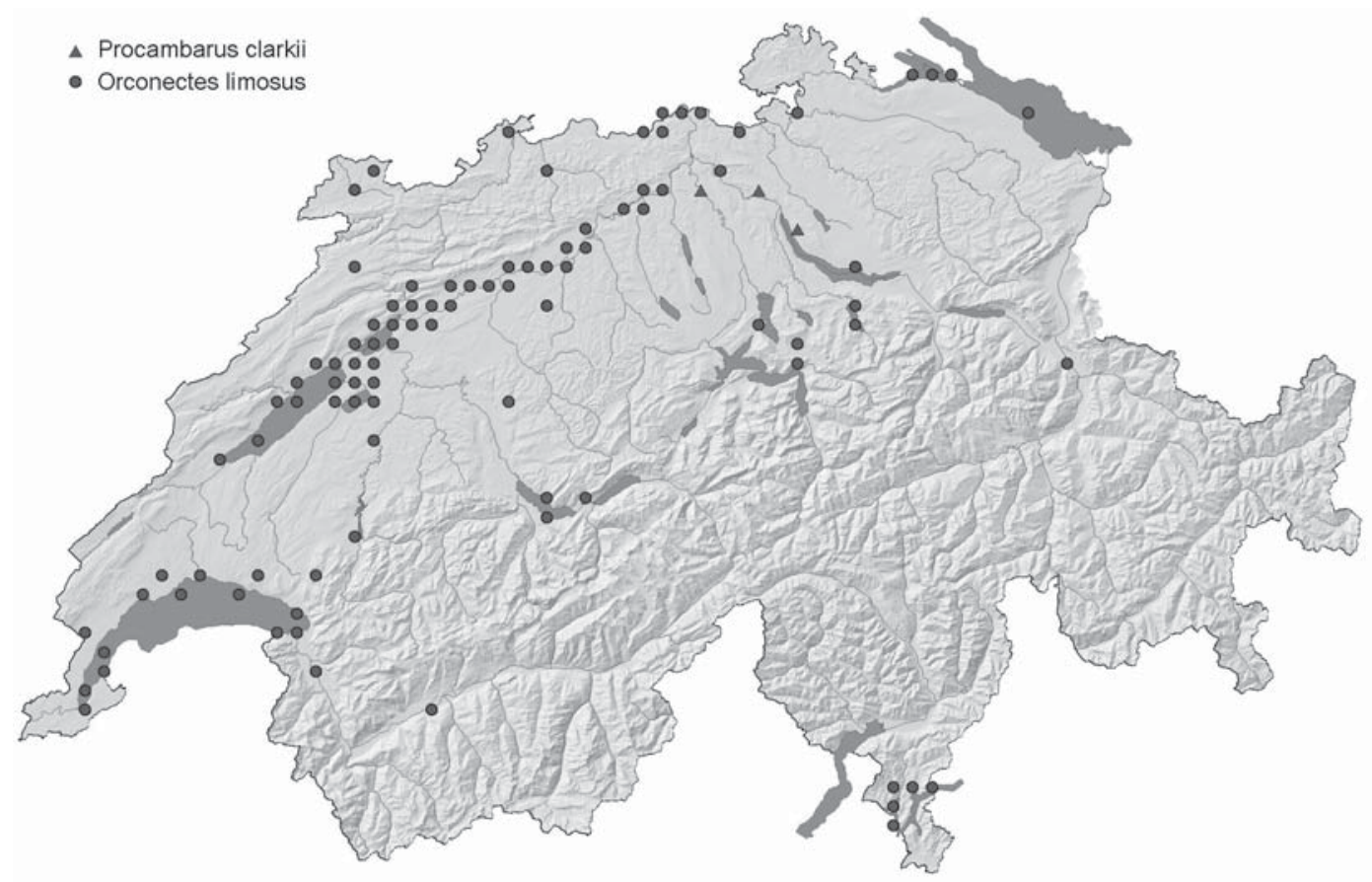

Figure 5

Current distribution of $\boldsymbol{O}$. limosus and of $\boldsymbol{P}$. clarkii. Each point represents a crayfish occurrence on a $5 \times 5 \mathrm{~km}$ grid.

\section{Figure 5}

Carte de distribution actuelle de 0 . limosus et de $P$. clarkii. Chaque point représente une occurrence sur une grille de $5 \times 5 \mathrm{~km}$.

\section{THE CRAYFISH PLAGUE: Aphanomyces astaci}

Among the four non-native crayfish species, three are potential carriers of the crayfish plague, acting as a vector for $A$. astaci. In order to get an overview of the presence of the pathogen at a national scale, the FOEN launched two campaigns in 2002 and in 2004 respectively: the local fisheries administrations were invited to collect live specimens of American crayfish species from different water bodies. The FOEN organized the collection of the material and its delivery to the University of Munich (Germany). There, the specimens were examined biochemically by Random Amplification of Polymorphic genomic DNA (OIDTMANN et al. 2004). RAPD-tests are used when the target sequence(s) to be amplified by PCR (Polymerase Chain Reaction) is unknown.

Investigations were carried out on about 650 specimens from 24 different sites. The results (LIMNOFISCH, 2002, 2004) are shown in Figure 6 and indicate how worrying the situation is. More than half of the sites (16) were tested positively for A. astaci, meaning that specimens were carrying the pathogen. The prevalence of the pathogen in certain populations has been evaluated as the ratio between the number of individuals tested positively and the total number of individuals investigated. This ratio was variable from population to population (Figure 6).

\section{LEGISLATION}

Crayfish are regulated by the National Swiss Fisheries Legislation (National Fisheries Law and its Implementing Ordinance), which came into force in 1994. The Legislation draws a legal distinction between native and non-native crayfish species. 


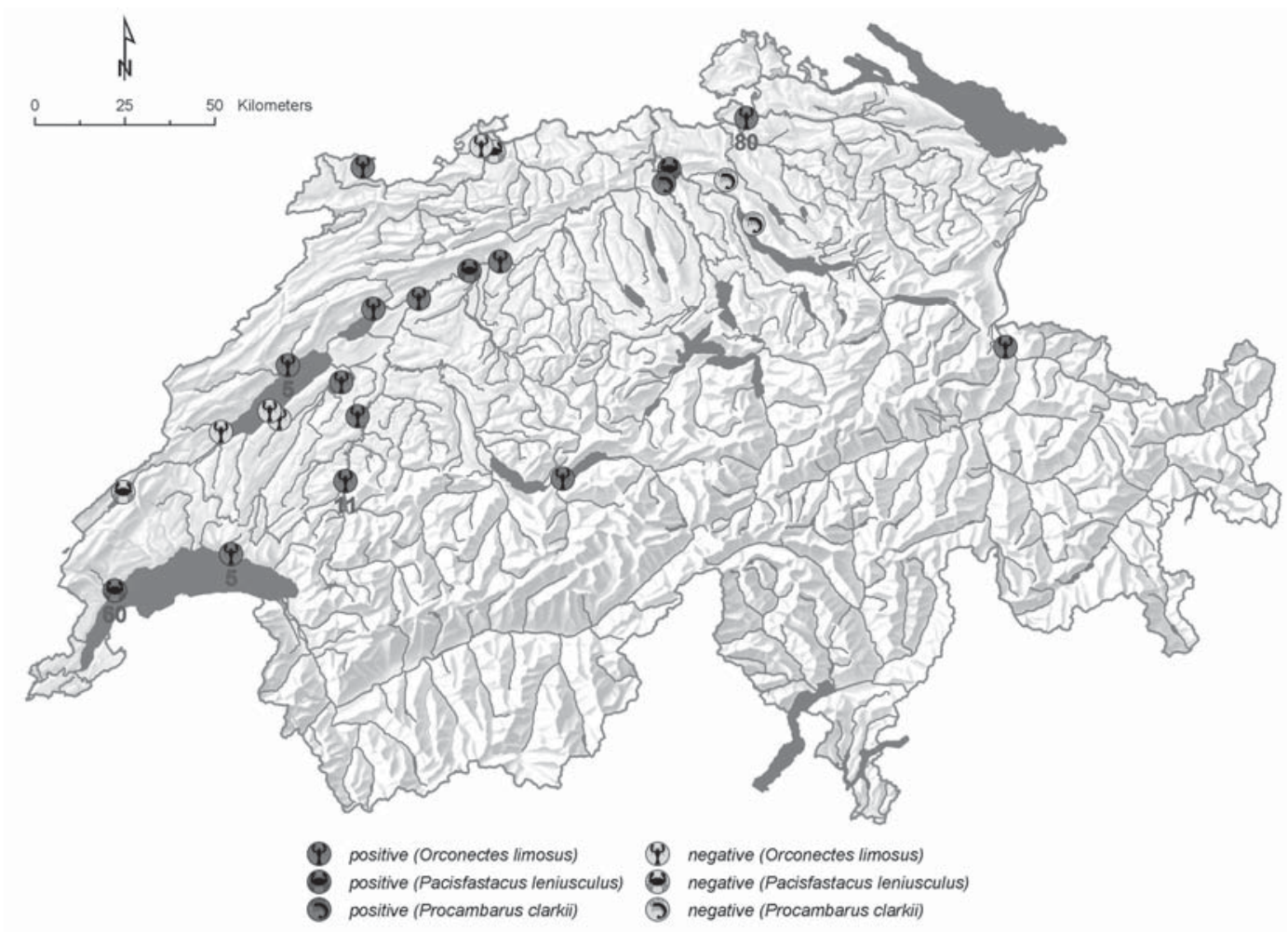

Figure 6

Populations of non-native crayfish investigated for the crayfish plague $A$. astaci. Red numbers indicate the prevalence of the pathogen in the population.

\section{Figure 6}

Populations exotiques testées pour le vecteur de la peste de l'écrevisse $A$. astaci. Les chiffres rouges indiquent la prévalence du pathogène dans la population.

Native species are listed with their distribution range (presence per catchment area) and degree of threat. The exploitation of native stocks is allowed; as for any exploitable fish, the Legislation defines a close season (40 weeks) and a minimum size for the catch $(12 \mathrm{~cm}$ for $A$. astacus and $9 \mathrm{~cm}$ for $A$. pallipes and A. torrentium, measured from the tip of the tail to the tip of the rostrum). The fishing pressure remains low and there are no complete statistics for the catch of crayfish at national level. The transport of live specimens is allowed, as is stocking within the natural range of distribution.

Every crayfish which does not belong to a native species is considered as a potential threat to the indigenous fauna and flora and, as a consequence, is undesirable. This general statement embodied in the law is translated into a strict regulatory policy: the importation and introduction of live non-native crayfish is strictly forbidden. Special authorization can be granted by the FOEN for public exhibitions and for scientific purposes. A more liberal approach has been tolerated for Yabbies (Cherax spp.), which can be imported and transported alive when kept in cool and close containers ("fridge crayfish") in order to allow a certain commercialization. This rule seems reasonable because Cherax spp. are sensitive to the crayfish plague and will die when infected. Furthermore the risk of escape is low under the specified conditions. But the guiding principle of "no non-native crayfish in any water body (including public or private garden ponds, aquaria or stocking basins used in aquaculture)" remains valid. 


\section{SWISS CRAYFISH MANAGEMENT PLAN}

A national management plan for crayfish has been developed by specialists including managers and scientists (STUCKI et al., 2005). The management plan is aimed at increasing the protective measures (PM) for native species and at enhancing population control (PC) for non-native ones.

\section{Protective measures for native species (PM)}

The measures proposed stem from experiences gathered in different Swiss cantons (MARCHESI et al., 1998; STUCKI, 2001, 2003). Because of the remoteness and the scattered distribution of most native populations, it is not possible to define extended zones of protection at national level. The main protective measures are aimed at conserving or rehabilitating the existing populations locally and, where possible, at widening their range.

\section{PM1: Definition of core populations for A. pallipes and A. torrentium}

The idea is to protect some large populations which could be used as a reservoir (genetic pools) for stocking or eventually for reintroduction programs (cf. PM3). Only healthy populations occupying at least several hectares (pond) or several $\mathrm{km}$ stretches (river, canal) should be chosen. Before applying protective measures (buffer zones, limitation of fishing or fish stocking, etc.), it is recommended that large-scale consultation should be undertaken among the people directly implicated (landowners, farmers, fishermen, etc.). Their integration in the process is crucial in order to reinforce the acceptance of the measures. Furthermore, local stakeholders have good knowledge of the locality and they could be helpful in identifying further risks and dangers (potential sources of pollution, etc.). Ideally, the negotiations have to be carried out under the auspices of a local authority (fisheries administration). Once the general concept has been accepted, we recommended launching a monitoring program in order to follow the evolution of the core populations and to evaluate how far they could be used for stocking or reintroduction programs. The health of the crayfish also needs to be regularly monitored. The management plan proposes 20 core populations for $A$. pallipes and 10 for $A$. torrentium distributed through the different catchment areas.

\section{PM2: Restoration and maintenance of habitat}

The idea is to perform restoration work on rivers, drainage canals and ponds targeting the specific ecological requirements of crayfish. By restoration, we mean any measure aiming to rehabilitate natural dynamics, particularly the free process of riverbank scouring and the reconstitution of the typical "riffle-pool" sequence of rivers. Restoration has high priority for sites potentially favorable for crayfish or where a large population has existed for a long time (before the correction of the river). Besides restoration, maintenance operations are also important: riparian vegetation should not be completely eliminated because riverbanks with dense vegetation and root systems plunging into water provide the best shelters for crayfish. When desilting canals, it is necessary to limit the operations to small stretches and not linearly along the whole canal. These operations can also be used to improve the riverbed structure, for example by digging deep pools.

\section{PM3: Reintroduction programs}

Reintroduction is not an easy task and has to be performed with caution. This measure should only be applied in the context of a conservation plan approved by the fisheries authorities. Furthermore reintroduction only makes sense when natural colonization from adjacent populations is no longer possible. Generally, it is justified where a crayfish population existed in the past, when the disappearance of the population has 
been elucidated in the meantime and when there are no longer grounds for concern. Before reintroducing crayfish, it is important to check certain key parameters which will determine the final outcome: there must be no connection (upstream or downstream) between the site being repopulated and any sick native or non-native crayfish populations (potentially vectors of the crayfish plague); the predatory pressure (fish) at the site must not be too high (some adaptations or the abandonment of fish stocking may be necessary); the genetic characteristics of the crayfish used for the reintroduction should be as identical as possible to the pristine population (cf. PM1). Finally, reintroduction of a species should not be performed in the presence of another crayfish species.

\section{PM4: Exploitation of population for $A$. astacus}

A. astacus has been introduced in Swiss waters for human consumption. Today, its use as food source is rather limited. Farming is marginal: ponds are usually managed on a small scale and there is no real inland production (STUCKI and STAUB, 1999). Exploitation is further limited by the lack of exploitable populations. But the economic interest could be enhanced and coupled with conservation measures. Some cultivated ponds have been restocked after population collapses (STUCKI and STAUB, 1999). One could imagine the promotion of stocking programs coupled with commercial exploitation, including special agreements with restaurant owners.

\section{Measures to control the non-native populations (PC)}

High competition and crayfish plague, both generated by the expansion of nonnative species, are the most acute threats. In this situation, implementation of protective measures alone will not be sufficient to halt the observed negative trend among native populations. Complementary measures aiming to reduce and control the expansion of non-native species are necessary. Prior to their current distribution and because of the limited financial and human resources available, eradication of the all non-native populations is unrealistic. That is why it is necessary to identify the most problematic species and to target the efforts where we have the best chance of success. As already mentioned, $A$. leptodactylus is in regression because of its vulnerability to the crayfish plague. $O$. limosus also does not represent an acute threat because it is confined to large rivers of the Plateau. For these reasons, the management plan proposes to focus on $P$. leniusculus and $P$. clarkii.

\section{PC1: Confinement and isolation measures}

Once established, a population will grow until saturation of the system. Up to this point, individuals start to emigrate and disseminate into a new environment. Confinement and isolation measures aim to prevent crayfish from reaching a new environment. This can be done by constructing a physical barrier like an overflow siphon in the case of a pond or by installing grids with trapping chambers upstream and downstream of a river stretch. When individuals colonize new habitats via a terrestrial route ( $P$. clarkii), it is necessary to fence the water body and to trap the individuals on the bank. Confinement measures are efficient but require a long-term survey and good collaboration between the different partners (local people, fisheries authority, users, etc.). Such measures have been applied with success in the case of $P$. clarkii (STUCKI, 2003), for which no new populations have been recorded in the past 9 years.

\section{PC2: Elimination program}

Elimination measures try to stabilize the size of a population at a low level. This is normally achieved by increasing the fishing pressure (anglers; trapping campaigns using baits or pheromones; introduction of natural predators), by poisoning the population or by technical operations (desiccation and treatment of ponds). 
Increasing the fishing pressure by anglers should not lead to widespread and uncontrolled transportation of live specimens, which is inevitably associated with risks of escape. This can be avoided by organizing prompt elimination campaigns supervised by the fisheries authority and grouping all societies from a region. The crayfish caught have to be killed immediately.

Trapping programs have been applied in the canton of Zurich in order to reduce a population of $P$. clarkii living in a pond of about 3 ha (BORNER et al., 1997; EAWAG, 2002). From 1997 to 2001 about 15.000 crayfish were caught using 7.000 traps with CPUE varying from 0.7 to 3.4 individuals per trap and night (FRUTIGER and MÜLLER, 2002). Up to 1999, natural predators (Anguilla anguilla, Esox lucius) were introduced to the pond. The combination of both measures was effective as shown by the number of crayfish caught, which declined progressively year after year. FRUTIGER and MÜLLER (2002) estimated the size of the population to have fallen from about 10.000 individuals in 1997 to about 1.000 in 2001.

Elimination programs using poisons (permethrin, fenthion) are delicate. Besides methodological problems, the acceptance of such initiatives is low. In 1995, the canton of Zurich planned to use fenthion (pesticide) to eradicate the above-mentioned population of $P$. clarkii. The announcement of such action met with strong opposition from local people and NGOs. After a heated debate, the eradication plan was definitively rejected in 1998 by a tribunal because of the existence of less problematic alternatives (trapping and introduction of natural predators).

Technical operations on the habitat (drying and treatment with lime) are non-specific and generally have a strong impact on the entire fauna and flora.

\section{PC3: Information and public awareness}

Despite strict regulations related to importation, transportation and introduction, non-native crayfish are still identified sporadically (pet, aquarium or water bodies). It is difficult to evaluate how far such occurrences are the consequence of voluntary illegal introductions or of ignorance. But considering the growing commercial interest in crayfish (particularly as pets) and the ease of obtaining exotic species (internet), the need to promote public awareness on the topic remains great.

\section{PC4: Monitoring of aphanomycosis}

As previously stated, the pathogen is widely distributed throughout Switzerland. This situation represents a chronic danger for the native crayfish species. The monitoring of the aphanomycosis organized by the FOEN should be maintained in order to record the evolution of the plague.

\section{PC5: Exploitation of non-native populations}

The exploitation of non-native populations is partially in contradiction with some principles embodied in the law (related to the live transport of specimens). Because of the massive increase of non-native populations in some lakes, a limited exploitation has been authorized for professional fisheries. Experiences are running allowing a controlled commercialization under strict conditions (each fisherman has to be registered by the local fisheries administrations, the selling of live crayfish is limited geographically, etc.).

Unlike professional fisheries, exploitation of non-native stocks by anglers should remain prohibited as long as no efficient killing method applicable in the field exists. This prohibition is justified by the risks of escape associated with the live transport of specimens. Exploitation by anglers remains possible in the context of elimination campaigns surveyed by the local fisheries authority (cf. PC2). 


\section{CONCLUSIONS AND OUTLOOK}

The form of crayfish management proposed by the FOEN is an attempt to conserve the native crayfish species in Swiss waters in a sustainable manner. Some parts of the management plan have already been in operation for a few years (regulations on importation, introduction and transport). The action that has already been implemented has partially fulfilled the initially stated objectives and, in general, can be considered as satisfactory. Some new regulations defining active measures against $P$. leniusculus and $P$. clarkii and enhancing protective measures for native species should improve the efficiency of the strategy launched at national level. But the final outcome of the program will depend on the support and commitment of the local fisheries authorities, which is related to the financial and human resources at their disposal. Furthermore, the implementation of the different measures will also require a communication strategy to improve the awareness of every stakeholder (including local administrations, fishermen, aquarium, pet and food supply stores, etc).

\section{ACKNOWLEDGEMENTS}

The authors are very grateful to B. Büttiker, M. Kugler, P. Marchesi, T. Stucki, J.D. Wicky and B. Zaugg for the development of the management plan. We would further like to thank E. Staub, P. Steiner and M. Droz for their constructive comments regarding improvements to the manuscript and N. Page for the correction of the English.

\section{REFERENCES}

BORNER S., BÜSSER T., EGGEN R., FENT K., FRUTIGER A., LICHTENSTEIGER T., MÜLLER R., MÜLLER S., PETER A. und WASMER H.R., 1997. Procambarus clarkii (Roter Sumpfkrebs) im Schübelweiher bei Küssnacht. Ökologische Situationsanalyse und Vorschläge zur Bekämpfung. EAWAG-Bericht, $22 \mathrm{~S}$.

BOTT R., 1972. Besiedlungsgeschichte und Systematik der Astaciden West-Europas unter besonderer Berücksichtigung der Schweiz. Revue Suisse de Zoologie, 13, 387-408.

BÜTTIKER B., 1980. Biologie und Verbreitung der Krebse in der Schweiz. Veröffentlichungen des Bundesamt für Umweltschutz und der Eidg. Fischereiinspektion, 39, 93-114.

BÜTTIKER B., 1987. Concerning Crayfish in Switzerland. Freshwater Crayfish, 7, 2-5.

CARL J., 1917. La répartition des écrevisses en Suisse. Arch. Sc. Phys. Nat. (4), 44, 476480.

CARL J., 1920. Décapodes (écrevisses). Catalogue des invertébrés de Suisse, 12, 1-32.

EAWAG, 2002. Roter Amerikanischer Sumpfkrebs (Procambarus clarkii) im Schübelweiher und Rumensee, Gemeinde Küsnacht ZH: Situation der Population im Sommer/ Herbst 2002 und Empfehlung für das weitere Vorgehen. EAWAG-Bericht, 8 S.

FRUTIGER A. und MÜLLER R., 2002. Der Rote Sumpfkrebs im Schübelweiher (Gemeinde Küsnacht ZH) Auswertung der Massnahmen 1998-2001 und Erkenntnisse. EAWAGBericht, 26 S.

LARGIADÈR C., HERGER F., LÖRTSCHER M. and SCHOLL A., 2000. Assessment of natural and artificial propagation of the white-clawed crayfish (Austropotamobius pallipes species complex) in the Alpine region with nuclear and mitochondrial markers. Molecular Ecology, 9, 25-37.

LAURENT P.J., 1983. Les écrevisses du Léman. Bull. de l'Association des Riverains et Usagers du Léman, 12, 5-6. 
LIMNOFISCH, 2002. Untersuchung von 9 Flusskrebsgruppen auf den Status als Carrier von Aphanomyces astaci (Krebspest). BUWAL-Bericht, $5 \mathrm{~S}$.

LIMNOFISCH, 2004. Untersuchung von 15 Flusskrebsgruppen auf Infektion mit Aphanomyces astaci (Krebspest). BUWAL-Bericht, $5 \mathrm{~S}$.

LÖRTSCHER M., STUCKI T., CLALÜNA M. and SCHOLL A., 1997. Phylogeographic structure of Austropotamobius pallipes populations in Switzerland. Bull. Fr. Pêche Piscic., 347, 649-661.

MADDALENA T., MARCHESI P., JANN B. and PALTRINIERI L., 1998. Inventario dei gamberi del cantone Ticino. Piano de Magadino e Mendrisiotto. Rapporto dell'Ufficio Maddalena \& Moretti. Museo Cantonale di Storia Naturale \& Pro Natura, Sezione Ticino, Lugano, $22 \mathrm{p}$.

MARCHESI P., VIEILLE A. et FOURNIER J., 1998. Les écrevisses du Valais. Bull. Murithienne, 116, 7-21.

MICKASCH T.M., 1999. Distribution of Austropotamobius pallipes and Orconectes limosus in the Swiss Midlands. Freshwater Crayfish, 12, 796-800.

OBRECHT U. und NIGGLI U., 1929. Grüsch, Land und Leute. Beitrag zur Landeskunde, 34 S. Druckerei Thöny, Brunner \& Co., Schiers.

OIDTMANN B, SCHAEFER N., CERENIUS L., SÖDERHÄLL K. and HOFFMANN R.W., 2004. Detection of genomic DNA of the Crayfish Plague Fungus Aphanomyces astaci (Oomycete) in clinical Samples by PCR. Veterinary Microbiology, 100 (3-4), 269-282.

STUCKI T., 1997. Three American Crayfish Species in Switzerland. Freshwater Crayfish, 7.

STUCKI T., 2001. Massnahmen zum Schutz der einheimischen Flusskrebsarten. Tagungband, Internationale Flusskrebstagung in Gaming-Niederösterreich.

STUCKI T., 2003. Bestandesmanagement von Procambarus clarkii und Pacifastacus leniusculus im Kanton Aargau. Tagungsband, 1. Internationale Flusskrebstagung des Forum Flusskrebs in Augsburg-Bayern.

STUCKI T., JEAN-RICHARD P., 1999. Atlas de distribution des écrevisses de Suisse. Informations concernant la pêche, OFEFP, 65, $41 \mathrm{p}$.

STUCKI T., ROMER J., 2001. Will Astacus leptodactylus displace Astacus astacus and Austropotamobius torrentium in Lake Ägeri, Switzerland? Aquatic Sciences, 63, 477-489.

STUCKI T., STAUB E., 1999. Distribution of Crayfish Species and Legislation concerning Crayfish in Switzerland. In: GHERARDI \& HOLDICH (ed.) Crustacean issues 11, Crayfish in Europe as Alien Species. How to make the best of a bad situation, 141147.

STUCKI P., ZAUGG B., 2005. Decapoda-Atlas. Fauna Helvetica. CSCF-Neuchâtel.

STUCKI P., ZAUGG B., BÜTTIKER B., HEFTI D., KUGLER M., MARCHESI P., STUCKI T., WICKY J.D., 2005. Plan d'action national pour les écrevisses. Rapport OFEV, $41 \mathrm{p}$. 
